Meta

Journal des traducteurs

Translators' Journal

\title{
Children's Literature and Translation Under the East German Regime
}

\section{Gabriele Thomson-Wohlgemuth}

Volume 48, numéro 1-2, mai 2003

Traduction pour les enfants

Translation for children

URI : https://id.erudit.org/iderudit/006971ar

DOI : https://doi.org/10.7202/006971ar

Aller au sommaire du numéro

Éditeur(s)

Les Presses de l'Université de Montréal

ISSN

0026-0452 (imprimé)

1492-1421 (numérique)

Découvrir la revue

Citer cet article

Thomson-Wohlgemuth, G. (2003). Children's Literature and Translation Under the East German Regime. Meta, 48(1-2), 241-249.

https://doi.org/10.7202/006971ar

\section{Résumé de l'article}

L'article décrit le statut de la traduction de la littérature est-allemande pour enfants pendant la guerre froide. Il donne brièvement une indication sur la valeur attribuée à la traduction et aux traducteurs par le régime socialiste. Finalement, il se concentre sur les principaux critères influençant la traduction des livres pour enfants et les facteurs économiques et idéologiques les plus significatifs. On y trouve aussi des exemples tirés de dossiers censurés par l'Allemagne de l'Est. 


\title{
Children's Literature and Translation Under the East German Regime
}

\author{
GABRIELE THOMSON-WOHLGEMUTH \\ University of Surrey, Guildford and Roehampton, London, United Kingdom \\ gaby@asgard1.freeserve.co.uk
}

\begin{abstract}
RÉSUMÉ
L'article décrit le statut de la traduction de la littérature est-allemande pour enfants pendant la guerre froide. Il donne brièvement une indication sur la valeur attribuée à la traduction et aux traducteurs par le régime socialiste. Finalement, il se concentre sur les principaux critères influençant la traduction des livres pour enfants et les facteurs économiques et idéologiques les plus significatifs. On y trouve aussi des exemples tirés de dossiers censurés par l'Allemagne de l'Est.
\end{abstract}

\begin{abstract}
This paper describes the status of translation and publication of East German children's literature during the period of the Cold War. It briefly gives an indication of the high value placed on translation and translators in the socialist regime. Finally it focuses on the main criteria influencing the translation and publication of children's books with the economic and ideological factors being the most significant and gives brief examples from the East German censorship files.
\end{abstract}

\section{MOTS-CLÉS/KEYWORDS}

Cold War, East German literature, economic factors, ideologic factors, socialist regime

\section{Introduction}

One generally refers to the German Democratic Republic (GDR) as a communist state. It, however, regarded itself as in the process of developing socialism on its way to communism, having overcome the historical epoch of capitalism/imperialism. According to Marxist dogma, socialism is seen as the logical and historically necessary period before the advent of communism. Therefore it was imperative for East Germany to introduce appropriate measures to pave the way forward and avoid falling back into capitalism. This could only be done by developing a socialist society, "to increase the socialist awareness of the masses, to actively instil Marxist-Leninist views and to insistently overcome egotism, individualism and other appearances of bourgeois ideology" (Mallinckrodt 1984:239).

Consequently, laws and regulations were put in place in order to create a new personality, the "new socialist being" and, along with it, a supporting socialist environment. Many of these regulations, however, also sought to fulfil a second objective, which was to secure power for the ruling party. As a result, the GDR represented an intricate system of political, economic and social legislation, of bureaucratic measures, propaganda and instruments of power. Because of this complexity, and also because little has been published about the state of translation in East Germany, this paper aims at describing the macro-level of information about general practices 
rather than the micro-level of detailed examples from translation practice. The discussion that follows is a synthesis of my current research into the translation of children's literature in the GDR which will be published in the near future as a $\mathrm{PhD}$ thesis. This paper is based mainly on my interviews with GDR translators, with people from the publishing industry and also on my study of the files of the East German Writers' Association and the GDR censorship files.

\section{Children's literature}

All art in the GDR was looked upon as a weapon in the class struggle. Therefore, literature, too, played a key role within the socialist framework and was widely used as a tool for education and indoctrination. Literary policy quite blatantly demanded that literature be partisan, i.e. loyal to the party line. Children's literature was assigned the same role and therefore held the same status as literature written for adults. With children's minds being even more impressionable than those of adults, it was clear that the influence would be more effective and longer lasting.

However, it was not only out of political and ideological motivation that children's literature received the same attention as adults.' Another reason for its high status stems from the fact that in a socialist society children are seen as people with equal rights. Together with the abolition of the class system, differences between adults and children have also been removed. "Children and youth are partners to the adults in the societal development process, [they are] allies in class struggle, active members of socialism and potential representatives of the future of the society" (Altner 1972:8).

The main task of children's literature was to be "purposeful" for children in their socialist development. During the 1950s and 1960s, in particular, the phase of socialist construction, children's books became a tool for propaganda, actively supporting the political and social development of the country by displaying a type of behaviour which conformed to the demands of a socialist society. Socialist Realism, as the main cultural concept, demanded the portrayal of life close to the "socialist reality," describing typical socialist characteristics and situations with an emphasis on the positive and optimistic in this new era. Children's literature idealised the communist world as the only "happy" one in which people find their true selves, free from any material constraints. The books aimed at portraying the future of the society, a society which would automatically come into existence once the conditioned children had grown up.

To achieve this end, children had to meet "heroes" who emulated the attitude of true socialist beings. Those heroes were model children, courageous, energetic and sacrificing, radiating optimism and a revolutionary attitude. The reader was expected to identify with them and to be encouraged to develop a similar behaviour. Another characteristic of these so-called "positive heroes" was their willingness to become integrated into the community. The "collective," within which people were united, was the supreme precept, individuality was not called for. "Books assigned youth a place in society that they were supposed to take. This place was to be found within a group or community [...]. The task of children's literature was to show how an individual young person, still searching, found their way to a collective, and how his/her striving for individual satisfaction found fulfilment through work for the sake of this collective" (Richter, as discussed in Wild 1990:384, 385). A striking example is the 
book "Tinko" by Erwin Strittmatter, published in 1954, thus marking the very beginning of socialism. This book was incorporated in the official canon of children's literature because of its significant theme. In it, a boy has to make a decision between his grandfather, a private land-owning farmer, and his father, who has returned from being a prisoner of war and now involves himself actively in building a socialist village. The plot propounds a process which was characteristic of the 1950s, whereby big landowners were expropriated and a land reform was introduced, featuring collective farming by many smallholders. Needless to say the boy eventually goes with his father and therefore with socialist reorganisation.

To the same extent as socialist maxims were integrated into literature, western influence was fended off. Western literature was regarded by the state as a serious threat; only approved literature was allowed. Especially before the erection of the Berlin wall, this policy expressed itself in fierce campaigns against all "evil" western imports. On a cultural level this meant destroying all trash literature which propagated the American way of life and which spread quickly and insinuated itself into the culture. A distinct danger was attributed to American comics which were claimed to idolise brute force as opposed to the noble liberation struggle of East German books. One example of such propaganda is illustrated by the following newspaper cutting from Tägliche Rundschau (18 May 1955):

"From Berlin we learn of the horrific crime of 13 year old Rudolf Scheffler who, in February, killed his aunt with a flat-bladed chisel [...]. He was under permanent influence of American trash films and crime books and, immediately after the murder, bought new trash books and went to watch a Tarzan film [...]" (Lettkemann 1994:13).

After a shift of power in 1971, literary policy entered a more liberal phase, albeit still dependant on the general political climate. The "new" protagonists in children's books were allowed to ask questions, to doubt, be helpless and insecure. Increasingly, they turned away from authoritarian thinking, formed their own personality independent of the collective and even articulated inconsistencies in the political and social system. However, the relationship to western ideology remained conflicting, and the maxim of hatred towards the class enemy, particularly West Germany and America, was rigidly upheld.

\section{Translation}

Immediately after the separation from West Germany after the war, East Germany defined its literary policy and stated which types of literature were supportive of the ideology and the formation of socialist awareness. One category embraced books from the cultural heritage which encompassed the foreign cultural heritage, as well. Bearing in mind the significance of books with respect to their social mission, translation was seen as a highly valued and respected profession. Translators were seen on an equal level to authors. Also, like the authors, they worked in both fields, that of children's literature and that of adult literature. Further, it should be noted that there was no difference in payment for the translation of children's versus adults' books, as the translation of books for children, and especially those for adolescents, were not deemed to be an "easier" job. As already stated, there was no discrimination between children's and adults' literature since both had the same important task to fulfil in society. 
The GDR took pride in the fact that they had created a culture of literary translation. On the one hand, the country aspired to present itself to the outer world with a progressive and cultivated image in order to counteract its reputation in the west of communist tightness and restriction. On the other hand, the cultural political task of the translator was taken very seriously to introduce the people to other cultures which were closed to them (SV 789 neu: 221). One must not forget that the majority of East Germans did not have the financial means to travel within the Eastern Bloc, nor the possibility of crossing the Iron Curtain and exploring western countries. This explains why all translators interviewed were very aware of the position they held in society. All of them felt they had been widely respected by the publishers and also by the general public for what they were doing. Translating in the GDR was not simply an isolated job behind a typewriter. Translators had plenty of opportunity to get in touch with their audience as they were sent round the country to read from their works.

Most East German literary translators were members of the Writers' Association. Admittedly, this was an organisation loyal to the Socialist Unity Party and, in its statute, even declared its closeness to the state ideology, but it also meant financial and intellectual support. Unlike technical translators, the literary translators were not represented by the Union. Thus, the Writers' Association took over this function. Within the association, translators held the same position as authors; the same rights were granted and the same facilities were open to them, such as courses, talks and even recreational facilities. The association also paid for them to go on international translation conferences which in the main took place in other socialist countries. However, there are cases known in which it even negotiated an exit permit for individual translators. It also had an influential say regarding the "standard contract," i.e. the contract according to which a translator was paid by the publisher.

These contracts meant that translators were relatively secure financially. Regarding their work, all the interviewees agreed that they had found their work fulfilling as there was no time pressure and they were able to focus on terms and style. Many of them admitted to having frequently overrun their allocated deadline and experienced no penalties. By and large, conditions were such that it took approximately two years for a book to make it to the market. This mainly resulted from delays due to socialist planning, approval methods and from constant shortages in materials. Once a manuscript had been returned to the publisher, it underwent a process of thorough proofreading and correction, followed by a meeting between the editor and the translator to make the last improvements and to agree on the version which was to be published.

\section{Criteria influencing translation and publication}

So far, I have described the necessity of a particular, partisan type of children's literature and the resulting high status of translators. I shall now turn to the question of which books were and were not translated and which criteria influenced the decision for and against a translation. My main focus will lie on translation from western literature. 


\section{Economic factors}

The first key factor was the East German economy. After 1945 it had lain in ruins and during the subsequent years it never fully recovered. Besides, the East German Mark could not be exchanged in western markets. Therefore, not only did the GDR have to deal with all sorts of restrictions in international trade, but it also could not keep up with the inflation from the world market, all of which were substantial factors in the growing depression of the economy. Having fallen behind to such an enormous degree, but at the same time choosing to carry on trade with the West and therefore increasing the position of dependency, presented a mounting problem (Wagner 1988: 72). As a consequence, all foreign economic transactions were closely scrutinised. With respect to the import of children's literature from the West this meant: will our youth gain from it and is it therefore worth paying precious foreign currency for it?

Many books were still protected under copyright law and, thus, royalties had to be paid in hard cash for the acquisition of rights. One can easily understand that the GDR, already desperately short on foreign currency, thought twice and three times before they decided to acquire the rights to a book. It is also evident that much emphasis was put on books for which the copyright had expired and hence were relatively cheap to translate and publish. This is the reason why many books from the classical canon could be found on the East German market. Transactions in kind rather than in cash were popular. A book stood much higher chances if a co-printing arrangement had been made with the west and, thus, the royalties were paid off in actual books. Some other, quite unconventional, methods were used e.g., granting authors cheap holidays in the GDR or "substituting suit-cases, made-to-measure suits or ladies' fur capes for hard cash." (Faber 1995: 23)

Once permission had been granted for a book to be translated, further obstacles could delay its publication considerably. Shortages in capacity, e.g., paper and ink, frequently brought about hold-ups or resulted in shorter print runs. Similarly, delays came about from urgent print jobs for state propaganda material or when a publication became ready for export into the West (which would result in a top up of much needed foreign currency). However, the interference with the publisher's business did not end there. As export trades were a state monopoly, all foreign currency transactions were regulated centrally. This meant that all foreign money earned had to be handed in and could not be re-invested by the publisher. From this central pot, money could only be obtained for a project after an application for funds. Very often this resulted in rejection due to shortages in the general supply of foreign currency. Particularly badly affected were the three private children's books publishers. Not only were they taxed extortionately, they generally suffered discrimination in terms of finance and materials. And even the two leading state publishers in the children's and youth book sector (Kinderbuchverlag, Verlag Neues Leben) that produced the considerable proportion of $90-95 \%$ of the annual market share in children's literature, regularly expressed discontent with the conditions under which they had to work.

\section{Ideological factors}

No less severe were the restrictions on translation stemming from ideological demands. As I have mentioned earlier, children's literature in the GDR was used as an educational 
tool for rearing young socialists. Sentimentalised books which portrayed the ideal world of a bourgeois society were not called for. Girls' books in which girls were depicted in a subordinate, weak role were rejected, as the socialist girl was to be active, brave and a fighter. Gundula Bahro expressed this new, socialist approach to girls' literature very clearly when criticising "the typical lower middle-class girls' book, such as the books by Arskaja in the USSR or those by Emmy von Rhoden in West Germany" (1976: 159). Books carrying this type of ideology were refused a printing permit outright, as happened in 1958 with Friedel Hart's "Hannele und Sannele." In his assessment, the evaluator found fault with the

"sentimentalised and kitschy atmosphere conveyed in nearly every page of the book. This distinct tendency to be a real tear-jerker gives the impression of a teenage girls' book as it is read in bourgeois society. The references to a present socialist society are too few which makes the book timeless in the negative sense of the word, as the story could have happened in West Germany or even 30 years ago. It does not show sufficient commitment to a socialist reality when, in a one-off scene, one of the doll makers describes how his great-grandfather was made to forego his position as a private toy maker, having to sell himself to a toys' distributor and since then had to live in misery. Therefore, searching for any value in this book, I do not find any. Despite a general deficit of girls' books, I cannot agree to a publication of this manuscript." (DR1/3993)

Similarly, all literature was ruled out which dealt with anti-Semitic, antisocial and anti-humanistic issues or which did not portray a clear and unquestionably progressive socialist image. So, for instance, censorship file DR1/3990 deals with a collection of children's poems in which some ideological shortcomings are sensed in some of the poems. The discussion about this manuscript even made its way up to the Party's Central Committee, where complete poems and parts of other poems were debated with respect to their suitability for children and for the possibility of misinterpretation. Criticism was, for example, directed at the moral of a poem called "Errors" (a full translation of this text is given below, including the moral, which caused the difficulty with the censors). The problem appears to have been that the moral could be "misinterpreted" as describing the greater errors of the socialist regime. However, in practice it was most likely intended as a simple teaching for young children. The censor's resolution of this problem was to remove the moral from the tale in the final publication of the poems (Peter Hacks "Der Flohmarkt").

ERRORS

A pink cat

and a sky-blue mouse meet on Anton's square

and immediately recognise each other.

The mouse wishes to hide, and then says he: worry not, I have never seen a pink cat lick his lips.

And the cat approaches quietly, bares his teeth and flares his whiskers, until he sees the strange fur of his lunch-to-be.

\section{IRRTÜMER}

\author{
Eine rosarote Katze, \\ eine himmelblaue Maus \\ treffen sich am Antonplatze \\ und erkennen sich durchaus. \\ Und die Maus will sich verstecken, \\ und dann sagt sie: keine Not, \\ nie sah ich das Maul sich lecken \\ eine Katze rosarot. \\ Und die Katze nahet leise, \\ bleckt den Zahn und steilt den Bart, \\ bis sie ihrer Mittagsspeise \\ sonderbares Fell gewahrt.
}


And he lets the mouse live,

because of the blue colour of his fur, and he says: this cannot be, a sky-blue mouse.

And both wander off the square, home without an incident, the cat to the right to Weissensee, the mouse to the left to Lichtenberg.

MORAL:

Although we do make errors, mostly things turn out well, my child, as the errors of others are so much greater [than our own].
Und sie lässt die Maus am Leben wiederum aufgrund des Blaus, und sie spricht: das kann's nicht geben, eine himmelblaue Maus.

Und sie wandeln von dem Platze ohne Zwischenfall nach Haus, rechts nach Weissensee die Katze, links nach Lichtenberg die Maus.

\section{GELEIT:}

Nämlich geht, auch wenn wir irren, meistens alles gut, mein Kind, weil die Irrtümer der andern immer noch viel größer sind.

All foreign literature had to meet the same ideological criteria as books written for the GDR market. This explains why the vast majority of translated books were Soviet or from other socialist countries. Another reason for the preponderance of Soviet books was to publicly give acclaim to the state, which was taken as a role model, and to its ideological outlook on life. This was apart from the economic considerations described earlier, whereby royalties for Eastern Bloc books were not only lower than for books from the West but also did not require expenditure of valuable western currency.

In order to have absolute control over the book market, the GDR installed an elaborate censorship system. For every book which was to be published, two, three or sometimes even more reports had to be submitted to the censorship authority within the Ministry of Culture. Inter alia, the reports had to explain why the book had been chosen by the publisher and in what way the children were to benefit from it. The reports reveal a formulistic, biased and cliché-ridden language which was intended to be concordant with the general party line and which was directed towards more easily passing the censorship hurdle. What counted was a compliance with socialist maxims and solidarity with the USSR. Particularly during the first two decades of the GDR, this attitude was followed dutifully and devotedly, as is exemplified in the file from the year 1953 on the book "Ulle Bam auf neuer Fahrt" by Georg Willroda. In the original manuscript, Ulle Bam and his friends, on their journey to China, do not stop over in Moscow but carry on with their journey. The complaint of the censorship authority was that

\footnotetext{
"Moscow could not be ignored and that at least the red star on the Kremlin must be mentioned. The 'improved' passage then read: In the distance a big, big town welcomed us: the magnificent Moscow with its marvellous historical buildings. We could clearly see the skyscrapers, the wide avenues and the bridges across the river. In the suburbs on the Lenin mountains, the world's largest university rose into the sky. The red star on the Kremlin tower shone brightly. Finele and Marcel wanted to land in Moscow immediately to visit this famous town, yet we had to continue our journey. [...] But I had to promise to visit Moscow on the next journey. For a long time, this had also been one of my great desires, only this takes much time, which unfortunately we did not have now. Again and again we turned round to have a look at Moscow, until this gigantic city disappeared on the horizon." (DR1/5107)
} 
As to the censorship files dealing with western books, a recurring pattern can be discerned. The most frequently claimed justification for having selected the book for translation was to depict a morally depraved capitalist west, inhuman, aggressive and drifting towards its unavoidable decline. Other reasons were to give positive examples for equality and against any elitist thinking, and also to show repressed individual creatures or peoples breaking free. From the study of the files it becomes evident that publishers exercised self-censorship by weighing criteria and only applying for promising projects. In the case of a problematic manuscript, they tended to anticipate and stress the weak points, hoping that in unison with an emphasis on important factors the book would pass the censorship hurdle. So in the case of the book “The House at World's End" by Monica Dickens (1975), where the publisher wrote,

"certainly this is not a book which aims at comprehensive unmasking of the capitalist society order, but it has been written from a progressive, humanitarian position, it contains sufficient overtones, critical of society, which will be interesting for our readers, and it has literary qualities which justify taking it on." (DR1/2274)

A book which did not experience any difficulty with the authorities was "Tales of Brer Rabbit," folktales of North-American blacks (1962). Brer Rabbit, the hero, is characterised as small and weak, having to fight against all types of predators. The file does not fail to mention that North-American negro slaves identified these predators with their own enemies, the slave dealers and plantation owners. It is very likely that this book was permitted immediately not only because of the allusion to the weak and unprotected but also because these tales had previously been published in the USSR (DR1/3958).

The final example shows a book which was not so fortunate to have such advocates and whose publication was hanging by a thread, because the external expert in her statement judged:

"Winnie the Pooh is exclusively about fantasy, happiness and child's play. Certainly our children are not less imaginative in their play, but it cannot be denied that the fantasy of our children moves in another direction. Our time is not so much about a single child with his toys on his own - and if this does prevail in a child, it is not desired and does not match our didactic ideals. Thus, the value for the education of our children is minimal and it is not worthwhile spending foreign currency on it. Yet, should it be taken on in exchange for publishing one of our valuable children's books in West Germany, a publication should not be refused." (DR1/5039a, 1959)

Without doubt, every culture attempts to exercise a certain degree of influence over what is published in their children's literature. However, this reached extremes in the GDR where children's literature was both elevated by the state to a place of high importance as an agent for cultural and educational development and at the same time rigidly planned and controlled in order to further the aims of the socialist system. Yet, despite the ideological rigidity, literary translation played a prominent role and translators were highly regarded, an aspect of translation which, regrettably, seems to have been lost since the reunification. 


\section{REFERENCES}

Altner, M. (1972): Das sozialistische Menschenbild in der Kinder- und Jugendliteratur der DDR Berlin: Kinderbuchverlag.

BAHRo, G. (1976): Brauchen wir eine spezielle Literatur für Mädchen? in: Weimarer Beiträge, Vol. $1,1976$.

Faber, E. (1995): Zur Geschichte der Plusauflagen: Freibeuterei ... ist keine Lebensform in: Börsenblatt für den Deutschen Buchhandel Vol. 11, 1995.

Lettkemann, G. und M. Scholz (1994): Schuldig ist ja schließlich jeder ... der Comics besitzt, verbreitet oder nicht einziehen läßt. Comics in der DDR - die Geschichte eines ungeliebten Mediums (1945/49 - 1990) Berlin: Mosaik Steinchen für Steinchen Verlag.

Maldinckrodt, A. (1984): Das kleine Massenmedium. Soziale Funktion und politische Rolle der Heftreihenliteratur in der DDR Köln: Verlag Wissenschaft und Politik Berend von Nottbeck.

Wagner, A. (1988): Kontinuierliches Wachstum oder Grenzen des Wachstum? in: G. Meyer, J. Schröder (1988eds) DDR heute: Wandlungstendenzen und Widersprüche einer sozialistischen Industriegesellschaft Tübingen: Narr.

WiLD, R. (1990ed) Geschichte der deutschen Kinder- und Jugendliteratur Stuttgart: Metzler.

\section{Censorship files}

DR1/5039a (Ministry of Culture)

DR1/5107 (Ministry of Culture)

DR1/3993 (Ministry of Culture)

DR1/3990 (Ministry of Culture)

DR1/3958 (Ministry of Culture)

DR1/2274 (Ministry of Culture)

\section{Files of the East German Writers' Association}

Stiftung Archiv der Akademie der Künste, Berlin: SV 789 neu 